\title{
5mC-hydroxylase activity is influenced by the PARylation of TET1 enzyme
}

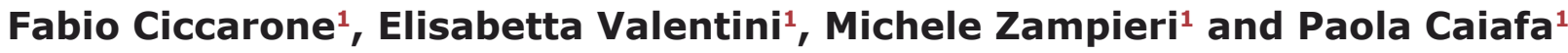 \\ ${ }^{1}$ Department of Cellular Biotechnologies and Hematology, "Sapienza" University of Rome and Pasteur Institute-Fondazione \\ Cenci Bolognetti, Rome, Italy \\ Correspondence to: Fabio Ciccarone, email: ciccarone@bce.uniromal.it \\ Paola Caiafa, email: caiafa@bce.uniroma 1.it
}

Keywords: PARylation, TETl, 5hmC

Received: March 18, $2015 \quad$ Accepted: May 30, $2015 \quad$ Published: June 15, 2015

This is an open-access article distributed under the terms of the Creative Commons Attribution License, which permits unrestricted use, distribution, and reproduction in any medium, provided the original author and source are credited.

\section{ABSTRACT}

\begin{abstract}
5-hydroxymethylcytosine is a new epigenetic modification deriving from the oxidation of 5-methylcytosine by the TET hydroxylase enzymes. DNA hydroxymethylation drives DNA demethylation events and is involved in the control of gene expression. Deregulation of TET enzymes causes developmental defects and is associated with pathological conditions such as cancer. Little information thus far is available on the regulation of TET activity by post-translational modifications. Here we show that TET1 protein is able to interact with PARP-1/ARTD1 enzyme and is target of both noncovalent and covalent PARylation. In particular, we have demonstrated that the noncovalent binding of ADP-ribose polymers with TET1 catalytic domain decreases TET1 hydroxylase activity while the covalent PARylation stimulates TET1 enzyme. In addition, TET1 activates PARP-1/ARTD1 independently of DNA breaks. Collectively, our results highlight a complex interplay between PARylation and TET1 which may be helpful in coordinating the multiple biological roles played by 5-hydroxymethylcytosine and TET proteins.
\end{abstract}

\section{INTRODUCTION}

Poly(ADP-ribosyl)ation (PARylation) is a posttranslational modification catalyzed by enzymes of the poly(ADP-ribose) polymerase (PARP) family, whose founding member is PARP-1 also known as ADPribosyltransferase diphtheria toxin-like 1 (ARTD1) [1] PARPs use $\mathrm{NAD}^{+}$as substrate producing negatively charged polymers of ADP-ribose (PARs) which are then hydrolyzed by the poly(ADP-ribose) glycohydrolase (PARG) [2-4]. DNA damage highly stimulates the activity of PARP-1/ARTD1 [5, 6], which functions as DNA break sensor PARylating DNA damage response effectors [710]. However, secondary DNA structures and allosteric trans-activating factors can also trigger PARylation $[6,11$, 12] supporting other housekeeping functions of PARP-1/ ARTD1 such as transcriptional regulation.

Besides the covalent PARylation of target proteins, PARP-1/ARTD1 itself and other PARP family members typically undergo automodification reaction $[3,6]$. Moreover, target proteins bringing specific PAR- interacting motifs are able to accommodate PARs noncovalently $[4,13]$. All these features of PARylation permit PARP-1/ARTD1 to modulate protein-protein interactions, subcellular localization or enzymatic activities [14-19]. Therefore, PARylation participates in a variety of cellular processes including DNA damage response, transcription and apoptosis $[3,16]$. PARP-1/ ARTD1 regulates gene expression acting on histones [20, 21], transcriptional factors (e.g. CTCF, SOX2) [22, 23] or proteins involved in chromatin dynamics (e.g. ISWI, HP1) $[24,25]$. Furthermore, PARP-1/ARTD1 is able to directly influence epigenetic events [26] also through the modification of enzymes involved in histone posttranslational modifications (e.g. KDM5B, KDM4D) [17, 27] or in the regulation of DNA methylation patterns (e.g. DNMT1, UHRF1) [19, 28].

As concerns DNA methylation, apart from inhibiting DNMT1 enzymatic activity by noncovalent PARylation [19], PARylated PARP-1/ARTD1 positively controls DNMT1 expression [29]. Recently, we have demonstrated that PARP activity is involved in the transcriptional 
regulation of the Ten-eleven-translocation 1 (TET1) gene $[30,31]$ codifying for an enzyme that introduces the 5-hydroxymethylcytosine $(5 \mathrm{hmC})$, a new epigenetic modification present on DNA.

$5 \mathrm{hmC}$ derives from the oxidation of 5 -methylcytosine $(5 \mathrm{mC})$ through the action of the 2-oxoglutarate/ $\mathrm{Fe}(\mathrm{II})$-dependent DNA dioxygenases TET1, TET2 and TET3 [32]. $5 \mathrm{hmC}$ can function as an intermediate of both passive and active DNA demethylation processes [33, 34]. The action of $5 \mathrm{hmC}$ in passive DNA demethylation seems to depend on the reduced binding affinity of the maintenance methylase DNMT1 for $5 \mathrm{hmC}$ [35]. As concerns active DNA demethylation, the presence of $5 \mathrm{hmC}$ is a prerequisite for sequential oxidation reactions, and even they are catalyzed by TET enzymes leading to formation of 5-formylcytosine (5fC) and 5-carboxylcytosine (5caC) [36]. Thymine DNA glycosylase (TDG)-mediated base excision repair (BER) has a pivotal role in the removal of $5 \mathrm{fC}$ and $5 \mathrm{caC}$ and re-introduction of unmethylated cytosine [37]. However, $5 \mathrm{hmC}$ is now considered as the sixth base of DNA introducing an additional epigenetic code onto genome $[32,38]$. In mammals, the levels of $5 \mathrm{hmC}$ are different in tissues and cell types. Brain and embryonic stem cells show the highest abundance of DNA hydroxymethylation $[39,40] .5 \mathrm{hmC}$ is depleted in stable heterochromatic regions, while it is frequently associated with promoterproximal regions, enhancers or transcription factor binding sites. Moreover, $5 \mathrm{hmC}$ is particularly enriched in $\mathrm{CpG}$ islands (CGIs) with low to medium GC-content but it is depleted in strong CGI which are generally completely unmethylated [41-44]. Genomic distribution of 5hmC mainly concentrated in proximity of coding sequences or of distal regulative elements supports the involvement of $5 \mathrm{hmC}$ in transcriptional regulation. Accordingly, a number of proteins display binding preference towards $5 \mathrm{hmC}$ thus functioning as readers of this modification and interpreters of the $5 \mathrm{hmC}$ epigenetic code. Notably, specific binders of $5 \mathrm{fC}$ or $5 \mathrm{caC}$ have also been identified $[45,46]$ and recent evidence has suggested the involvement of these additional DNA modifications in the regulation of transcription influencing RNA polymerase II activity as well as DNA methylation dynamics on active promoters [47-49]. Besides a role of PARylation in preserving a permissive chromatin state on TET1 gene promoter [31, 50], an involvement of PARs has also been demonstrated for the recruitment of TET1 protein onto specific loci during adipocyte differentiation [51]. Considering the multiple ways of action of PARylation in the regulation of protein functions $[6,16]$, we decided to investigate further the interplay between TET1 and PARP-1/ARTD1. All in all, our results highlighted that TET1 is a target of both covalent and noncovalent PARylation with consequences on TET enzymatic activity and that TET1 is in itself able to stimulate PARP-1/ARTD1 activation.

\section{RESULTS}

\section{PARP inhibition affects TET1-mediated $5 \mathrm{hmC}$ formation}

HEK293T cells were treated with two competitive inhibitors of PARP activity, Pj-34 and ABT-888. Both PARP inhibitors provoked the disappearance of PAR levels which was associated with a reduction of TET1 protein (Figure 1A). The transcriptional analysis of the main genes codifying for PARP machinery members (i.e. PARP-1, PARP-2, PARP-3 and PARG) showed no differences after PAR depletion (Supplementary Figure S1). Dot-blot and ELISA-based $5 \mathrm{hmC}$ quantification analyses evidenced that the inhibition of PARP activity caused a moderate reduction of the global content of $5 \mathrm{hmC}$ with respect to control cells (Figure 1B and Supplementary Figure S2A). The silencing of TET1 (Figure 1C) was performed to analyse the involvement of TET1 activity in the formation of $5 \mathrm{hmC}$ in HEK293T and its contribution to the effects mediated by PARP inhibition. $5 \mathrm{hmC}$ dot-blot analysis showed that silencing of TET1 markedly decreases the formation of $5 \mathrm{hmC}$ in HEK293 $\mathrm{T}$ with respect to CTRLsilenced cells. Notably, the effect of PARP inhibition on $5 \mathrm{hmC}$ formation was no longer evident after the silencing of TET1 indicating that TET1 protein has a major role in this phenomenon in HEK293T cells (Figure 1D).

\section{The action of PARylation on TET1 enzyme is not limited to protein recruitment}

Engineered transcription activator-like effector (TALE) is customizable DNA-binding domain designed to target specific sites on genome [52]. We decided to use TALEs fused to TET1 protein [53] to obtain a recruitment of TET1 onto DNA independently of PARylation (Figure 2A). In fact, the noncovalent PARylation of murine TET1 has been described as being involved in the recruitment of this protein on specific loci during adipocyte differentiation [51]. Being TALE constructs fused to the human TET1 protein, we confirmed the conservation of putative PAR-binding motifs in it. Moreover, we identified an additional site for noncovalent PARylation in an aminoacid sequence of the human TET1 catalytic domain absent from the murine TET1 protein (Supplementary Figure S3).

Blast analysis of two sequences recognized by two different TALE-TET1 full-length proteins (FL-1 and FL-2) showed that similar DNA regions are randomly distributed on genome (data not shown). According to this, a global increase of $5 \mathrm{hmC}$ levels was effectively evidenced after overexpression of FL-1 or FL-2 TALE-TET1 proteins (Figure 2B and Supplementary Figure S4A). Notably, treatment with the PARP inhibitor ABT-888 of HEK293T 

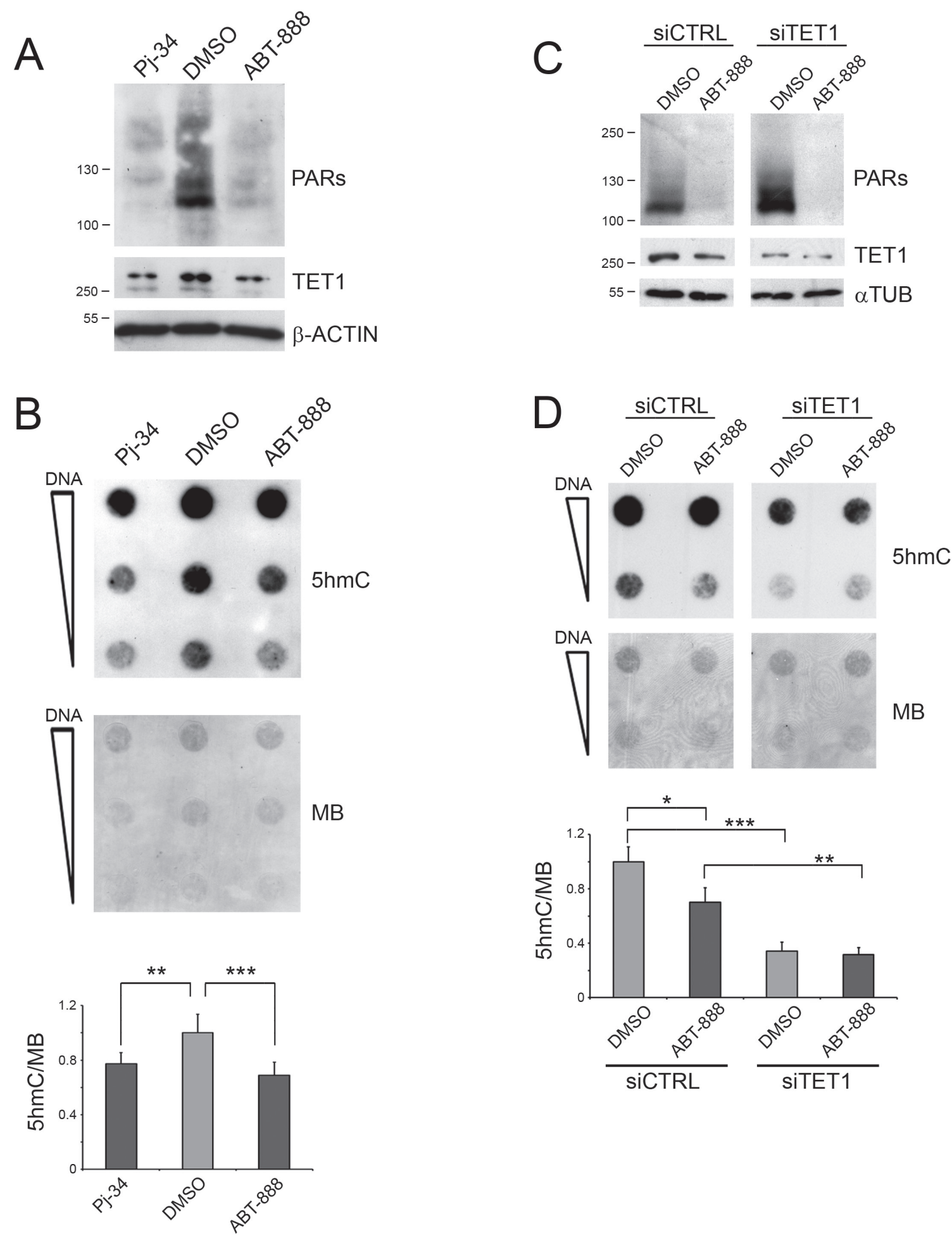

$\mathrm{MB}$

Figure 1: Inhibition of PARP activity affects TET1-dependent $5 \mathrm{hmC}$ formation. A. Western blot analysis showing the effect of PARP inhibition on HEK293T cells treated with Pj-34 and ABT-888 for $72 \mathrm{hrs}$. B. $5 \mathrm{hmC}$ dot-blot analysis after inhibition of PARylation for $72 \mathrm{hrs}$ and relative quantification. Results are shown as means \pm S.E.M. $(n=5)$. C. Western blot analysis showing the silencing of TET1 and the levels of PARs after ABT-888 treatment. D. $5 \mathrm{hmC}$ dot-blot analysis and relative quantification after inhibition of PARylation for 72 hrs in control (siCTRL) and TET1-silenced (siTET1) cells. Results are shown as means \pm S.E.M. $(n=4)$. Quantification of $5 \mathrm{hmC}$ levels was performed by densitometric analysis using methylene blue (MB) staining as DNA loading control. $P$-values were determined by ANOVA with post hoc Tukey's test $(* P<0.05 ; * * P<0.01 ; * * * P<0.001)$. 
cells overexpressing TALE-TET1 FL induced new increase of $5 \mathrm{hmC}$ levels with respect to untreated cells (Figure 2C and Supplementary Figure S2B). These results highlight the existence of additional roles played by PARylation on $5 \mathrm{hmC}$ formation, which are independent of TET1 recruitment on genome. To investigate a possible regulation of TET activity mediated by PARylation, two different TALE proteins fused only to TET1 catalytic domain (CD-1 and CD-2) were overexpressed (Figure 2D and Supplementary Figure S4B). Also TALE-TET1 CD overexpression caused a global increase of $5 \mathrm{hmC}$ (Figure 2E), which even in this case was more evident after the inhibition of PARP activity (Figure 2F and Supplementary Figure S2C).

\section{TET1 is a protein partner of PARP-1/ARTD1}

A possible direct influence of PARylation on TET1 activity would imply an interaction between PARP-1 and TET1 proteins. Therefore, co-immunoprecipitation experiments were performed by using anti TET1 or anti PARP-1 antibodies demonstrating the binding between these proteins. Notably, after treatment with the PARP inhibitor ABT-888, the binding between TET1 and PARP1 was partially affected suggesting that it is stabilized by PARs (Figure 3A).

Further demonstration of the interaction between TET1 and PARP-1 was obtained through GST pull-down experiments by using a GST-tag fused to the catalytic domain of TET1 (GST-TET1) presenting the PAR-
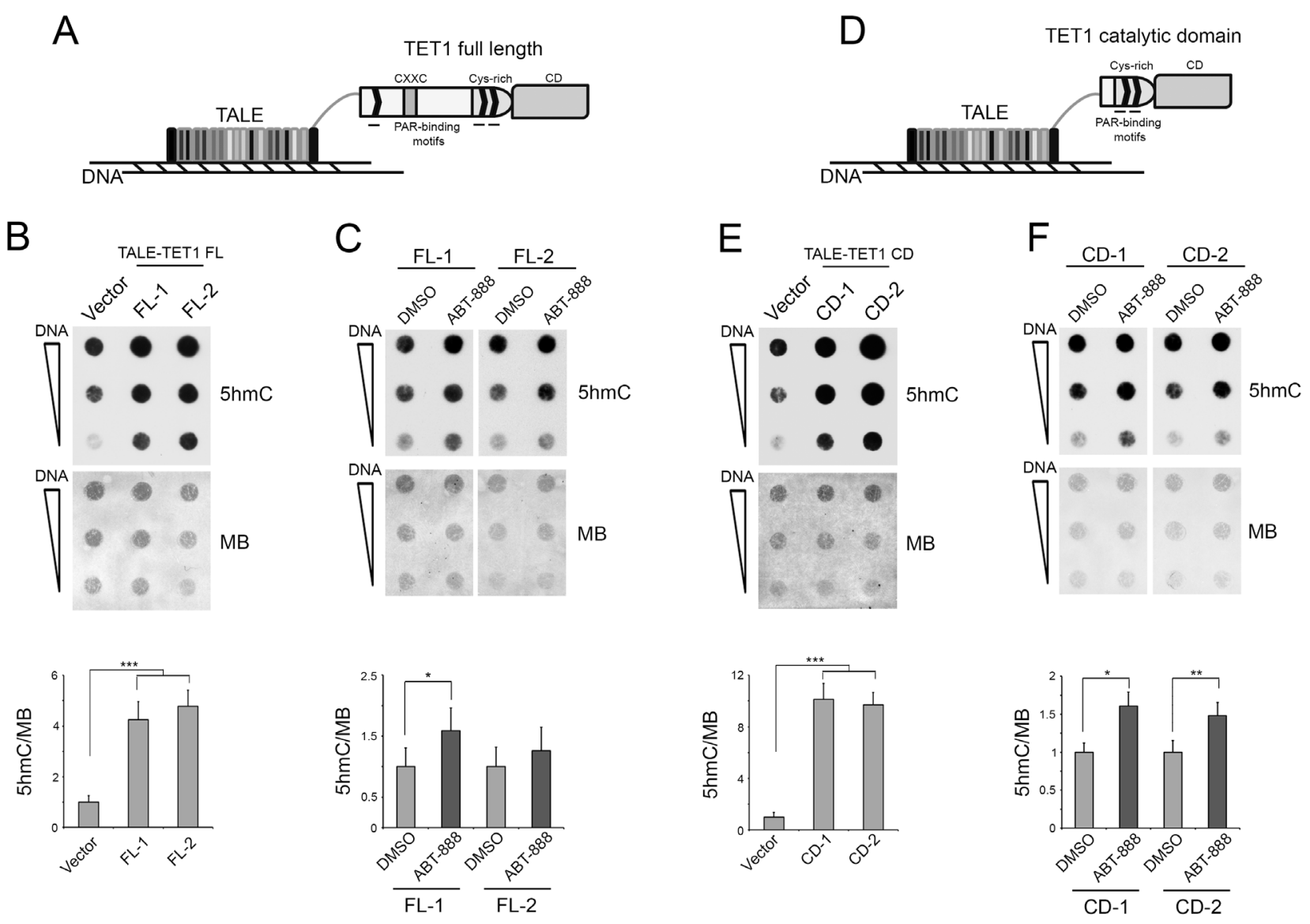

Figure 2: The levels of $5 \mathrm{hmC}$, deriving from TALE-TET1 protein overexpression, increase after PARP inhibition. A. Schematic illustrating the TALE fused to TET1 full-length protein (TET1 FL) containing the CXXC-type zinc-binding domain (CXXC), the cysteine-rich region (Cys-rich), the catalytic domain (CD) and the PAR-binding motifs. B. Dot-blot analysis of $5 \mathrm{hmC}$ after overexpression of two different TALE-TET1 FL (FL-1 and FL-2) proteins for $72 \mathrm{hrs}$. Results are shown as means \pm S.E.M. $(n=3)$ C. Dot-blot analysis of $5 \mathrm{hmC}$ after overexpression of FL-1 and FL-2 and inhibition of PARP activity. Results are shown as means \pm S.E.M. $(n=3)$. D. Schematic illustrating the TALE fused to the catalytic domain of TET1 protein (TET1 CD) containing the cysteine-rich region (Cys-rich), the catalytic domain (CD) and the PAR-binding motifs. E. Dot-blot analysis of 5hmC after overexpression of two different TALE-TET1 CD (CD-1 and CD-2) proteins for $48 \mathrm{hrs}$. Results are shown as means \pm S.E.M. $(n=3)$. F. Dot-blot analysis of $5 \mathrm{hmC}$ after overexpression of CD-1 and CD-2 and inhibition of PARP activity. Results are shown as means \pm S.E.M. $(n=3)$. Quantification of 5 hmC levels was performed by densitometric analysis using methylene blue (MB) staining as DNA loading control. P-values were determined by ANOVA with post hoc Tukey's test or paired Student $t$-test $(* P<0.05 ; * * P<0.01 ; * * * P<0.001)$. 
binding motif typical of the human protein. Incubation of GST-TET1 with HEK293T nuclear extracts evidenced that endogenous PARP-1 is able to bind the C-terminal catalytic domain of TET1 (Figure 3B). GST pull-down was also performed in presence of recombinant PARP1 indicating that the binding to TET1 is actually direct (Figure 3C).

\section{TET1 protein binds PARs noncovalently}

Immunoprecipitation experiments were performed with anti PAR antibodies confirming that endogenous TET1 is a target of PARylation (Figure 4A). In vitro PARbinding assays with either free PARs or PARP-1 attached PARs were performed to demonstrate that TET1 catalytic domain is able to bind PARs noncovalently. PAR blot assay was carried out spotting 3-fold serial dilution of GST-TET1, histone H2B as positive control and GST-tag as negative control. Incubation with free PARs followed by anti PAR immunoblotting demonstrated the capacity of TET1 for binding PARs noncovalently. Notably, the interaction between PARs and TET1 catalytic domain persists even in presence of an excess of competitor double-stranded DNA (dsDNA) used to rule out nonspecific interactions due to the highly negatively charged nature of PARs (Figure 4B). GST pull-down experiments performed by using in vitro automodified PARP-1 demonstrated that TET1 is able to bind PARs even when they are present on PARP-1 protein (Figure 4C).

\section{Inhibitory effect of noncovalent PARylation on TET1 activity}

To verify whether PARylation is effectively able to influence TET1 hydroxylase activity, HEK293T cells were treated with the PARP inhibitors $\mathrm{Pj}-34$ and ABT888 (Supplementary Figure S5) and TET activity was measured in vitro. An increase of total TET activity was

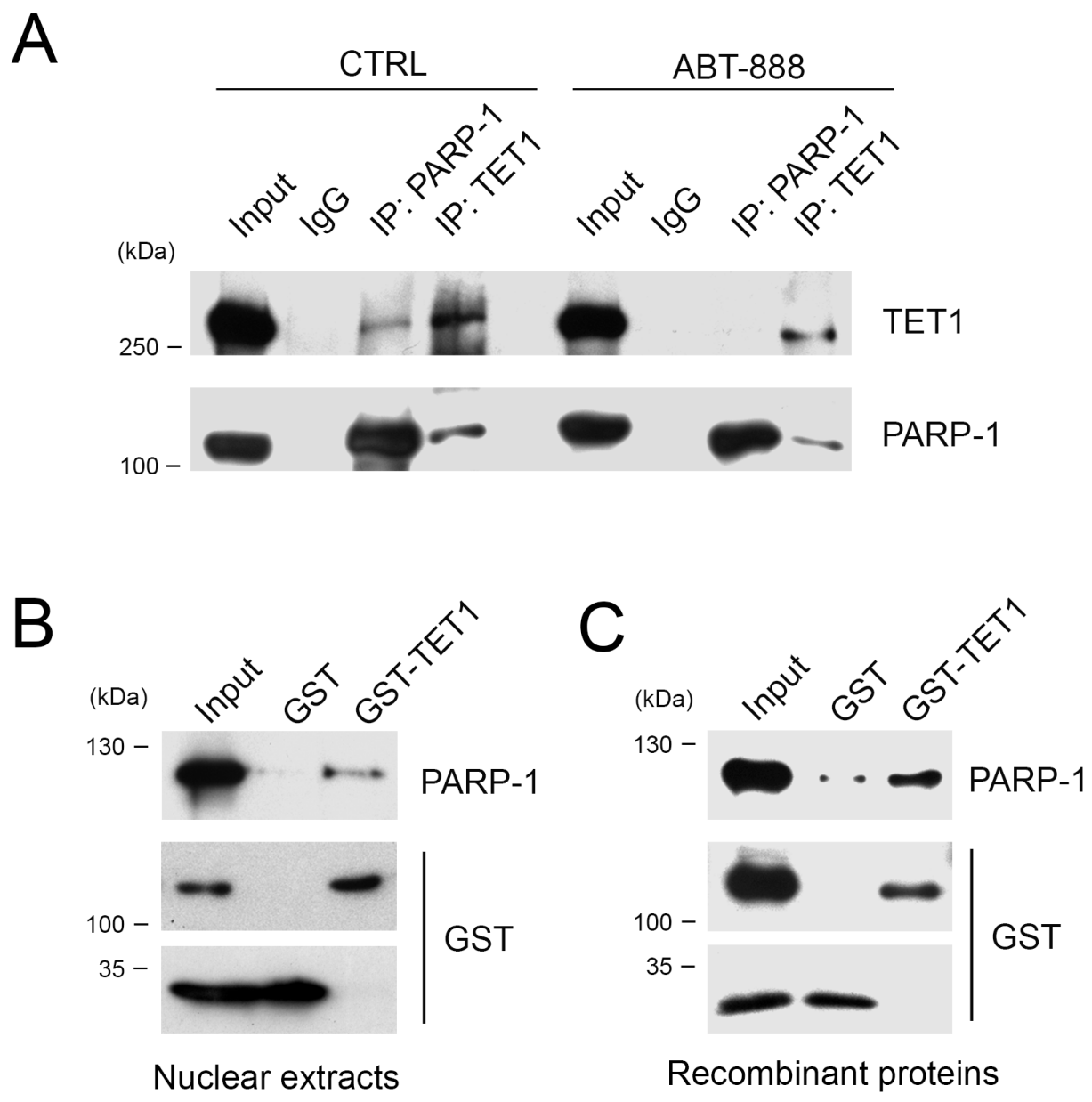

Figure 3: TET1 interacts with PARP-1 protein also in absence of PARs. A. Co-Immunoprecipitation experiments performed with anti TET1 or anti PARP-1 antibodies on nuclear lysates of HEK293T treated or not with ABT-888 for 6 hrs. Input lysate was $10 \%$ of total. B. GST pull-down performed by using GST-TET1 and GST as control in presence of HEK293T nuclear lysates or C. recombinant PARP-1 protein. 
evidenced in absence of PARylation thus suggesting an inhibitory role of PARs on TET enzymes (Figure 5A).

To test the effect of noncovalent PARylation on TET1 enzymatic activity, GST-TET1 was incubated with PARs synthetized in vitro and purified. Notably, a reduction of TET1 hydroxylase activity was observed in presence of PARs suggesting that the noncovalent PARylation of TET1 catalytic domain is able to inhibit TET1 activity (Figure 5B).

\section{TET1 is covalently PARylated}

Besides noncovalent PARylation, proteins can also be covalently modified by PARs. To test whether TET1 can also be a target of covalent PARylation, an in vitro PARP assay was performed incubating GST-TET1 with recombinant PARP-1, NAD ${ }^{+}$and nicked DNA to induce PARP activation. Western blot analysis with anti PAR antibodies evidenced time-dependent smears corresponding to PARP-1 activation. Moreover, the anti PAR antibody also revealed bands coincident with GSTTET1 molecular weight (arrow) indicating that TET1 is covalently PARylated in vitro. Notably, GST-TET1 sample incubated for 20 min with PARP-1 showed a more intense high molecular weight smear obtained with anti PAR antibody than the corresponding GST control sample suggesting that TET1 protein may have in itself the capacity for stimulating PARP activity (Figure 6A). Based on this, additional experiments were performed incubating GST-TET1 or GST alone with PARP-1 but in absence of activating nicked DNA. The incubation of PARP-1
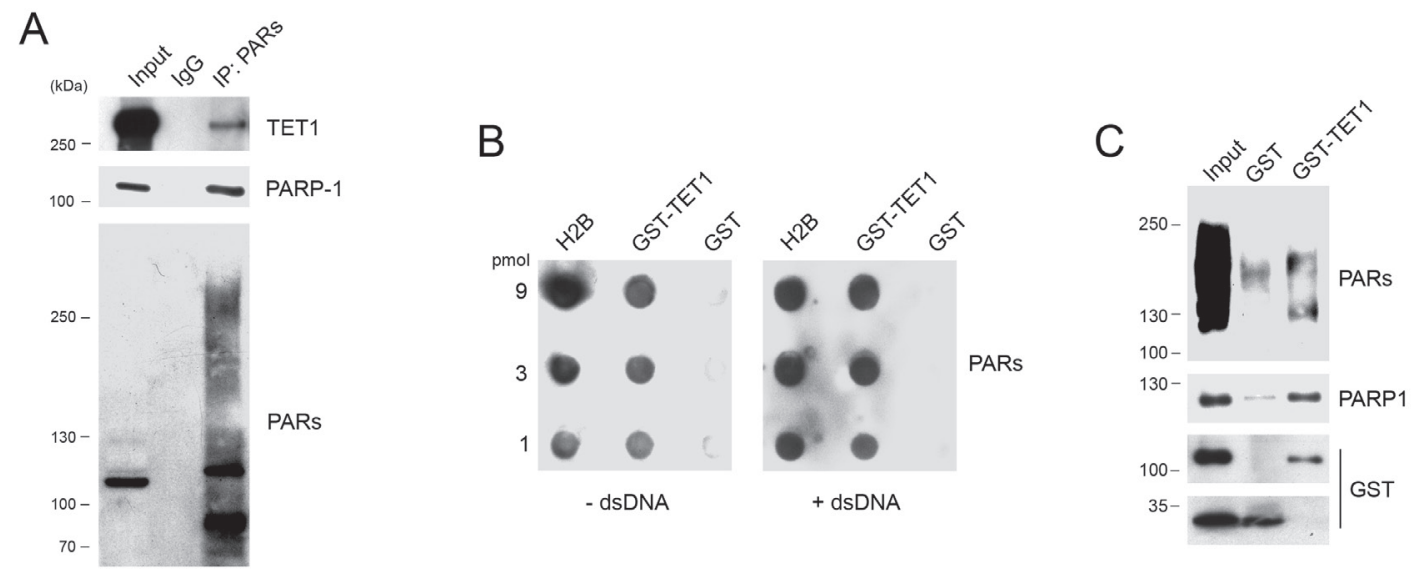

Figure 4: TET1 interacts noncovalently with PARs. A. Immunoprecipitation experiments performed with anti PAR antibody on HEK293T nuclear lysates. Input lysate was $10 \%$ of total. B. PAR blot assay of GST-TET1, GST alone (negative control) and histone H2B (positive control) incubated with free PARs with/without dsDNA as competitor. C. GST pull-down performed by using GST-TET1 and GST as control in presence of automodified PARP-1 protein.

A

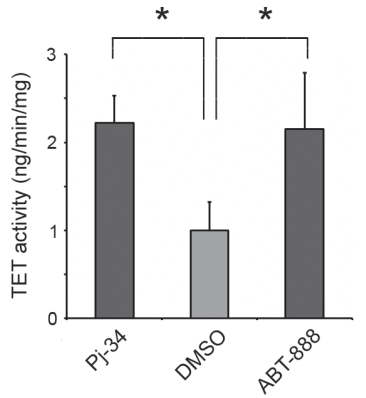

B

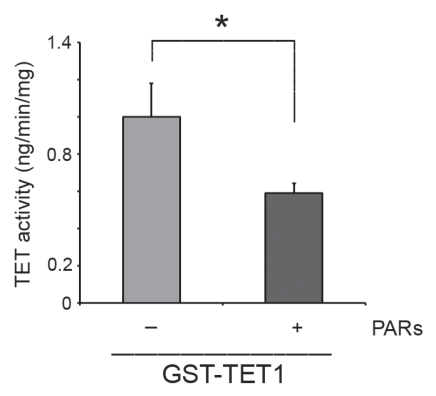

Figure 5: TET1 activity is negatively influenced by noncovalent PARylation. A. 5mC-hydroxylase TET activity measured in nuclear extracts of HEK293T treated or not with PARP inhibitors for 6 hrs. Results are shown as means \pm S.E.M. ( $n=3$ ). B. 5mChydroxylase TET activity of recombinant GST-TET1 enzyme measured in presence/absence of PARs. Results are shown as means \pm S.E.M. $(n=5)$. P-values were determined by ANOVA with post hoc Tukey's test or paired Student $t$-test $(* P<0.05)$. 
with GST-TET1 for different times (Figure 6B) or with different concentrations of GST-TET1 (Figure 6C) showed a time- and dose-dependent increase of anti PAR signal, respectively. These results allowed the demonstration that TET1 is effectively able to activate PARP-1 independently of DNA damage. Notably, the presence of bands coincident with GST-TET1 molecular weight (arrow) detectable with anti PAR antibodies indicated that following the stimulation of PARylation by TET1, PARP-1 is in turn able to covalently modify TET1 protein (Figure $6 \mathrm{~B}$ and $6 \mathrm{C})$. The possibility that the covalent modification
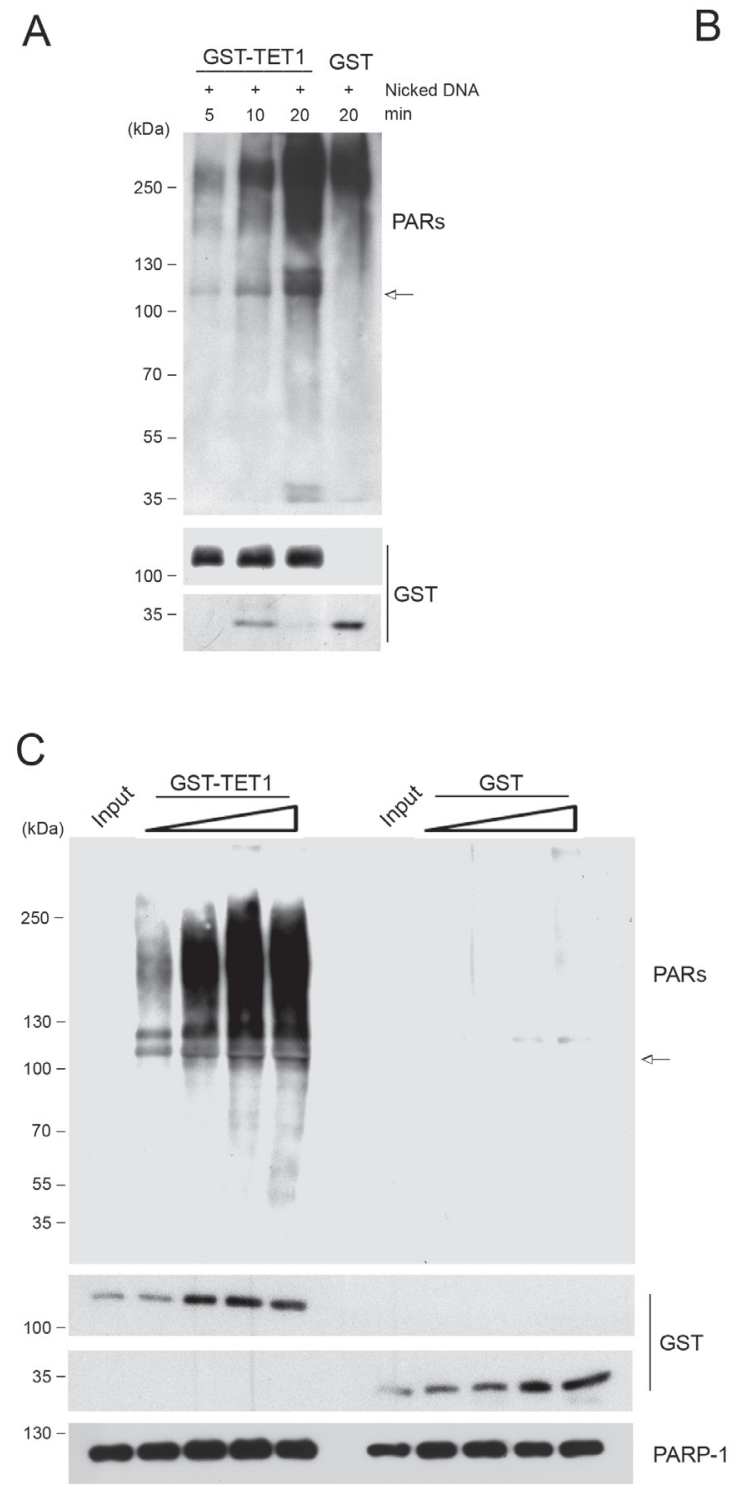

of TET1 may modulate the activity of TET1 protein was tested purifying PARylated GST-TET1 and measuring its hydroxylase activity in vitro. This assay suggested that the covalent PARylation of TET1 stimulates TET enzymatic activity (Figure 6D).

\section{DISCUSSION}

The complexity of events involving $5 \mathrm{hmC}$ and its derivatives implies a fine-tuned regulation of TET protein activities to coordinate their actions [54]. Post-translational
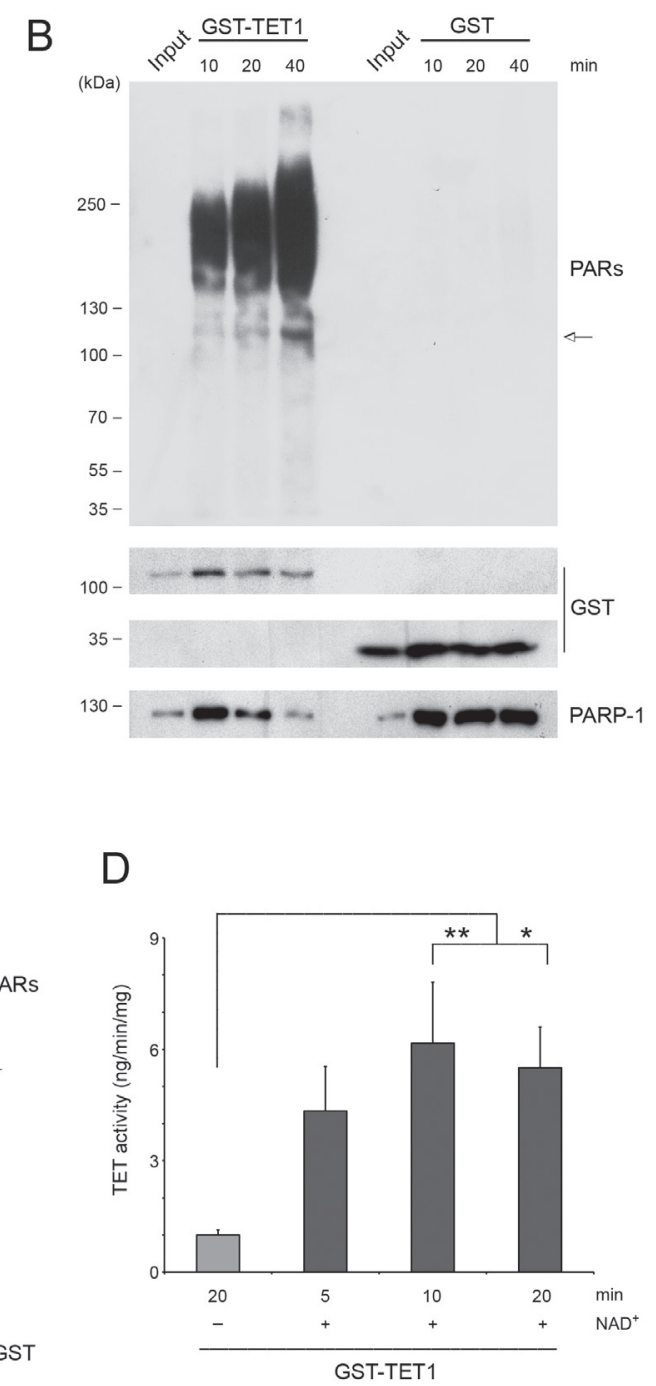

Figure 6: TET1 is covalently PARylated and is able to activate PARP-1. A. In vitro PARylation assay performed incubating PARP-1 with GST-TET1 for different times or with GST alone (negative control), in presence of nicked DNA added to stimulate PARP activity. B. In vitro PARylation assay in absence of nicked DNA performed by using PARP-1 with GST-TET1 or with GST alone (negative control) for different times or C. at different concentrations. D. 5mC-hydroxylase TET activity of GST-TET1 covalently modified by PARP-1. Results are shown as means \pm S.E.M. $(n=4)$. P-values were determined by ANOVA with post hoc Tukey's test $\left({ }^{*} P<0.05\right.$, $* * P<$ 0.01). Arrows indicate the bands revealed by anti PAR antibodies and corresponding to GST-TET1 molecular weight. 
modifications are typically known to expand the range of functions of protein influencing subcellular localization, protein-protein or protein-nucleic acid interactions as well as enzymatic activities. The most studied modification of TETs is certainly the O-linked glycosylation catalysed by the O-linked N-acetylglucosamine (O-GlcNAc) transferase (OGT), which is able to modify all TET proteins but with different functional outcomes [55]. For example, while TET1 glycosylation seems to enhance protein stability [56], TET3 glycosylation regulates the subcellular localization [57]. Glycosylation of TETs also affects their phosphorylation which has recently been identified on TET proteins but whose function is still unknown [58]. In parallel, TET proteins are able to influence OGT activity with consequences on histone modifications and transcription [59].

An interesting link has also been observed between TET enzymes and PARylation $[31,51,60]$. TET1 is able to bind PARs noncovalently as it brings a PAR-binding motif within the N-terminal domain and another two motifs adjacent to the catalytic domain. The noncovalent PARylation of TET1 was demonstrated to be involved in the recruitment of TET1 onto specific loci by a PARylated protein complex comprising also PPAR $\gamma$, which is the key regulatory factor in adipogenesis [51]. In addition, we have recently demonstrated a transcriptional control of TET1 gene mediated by PARylation [31], result also confirmed by another group [50]. The well-known ability of PARP-1/ARTD1 to regulate protein functions by several modes $[6,16]$ prompted us to investigate further the interplay between PARylation and $5 \mathrm{hmC}$ formation focusing on TET1 enzymatic activity.

The use of TALE-TET1 fusion proteins (TET1 full-length or catalytic domain) highlighted new roles played by PARylation on TET1 function independently of protein recruitment which now is mediated by TALEs. Their overexpression induced an increase of $5 \mathrm{hmC}$ levels which was even more evident in presence of PARP

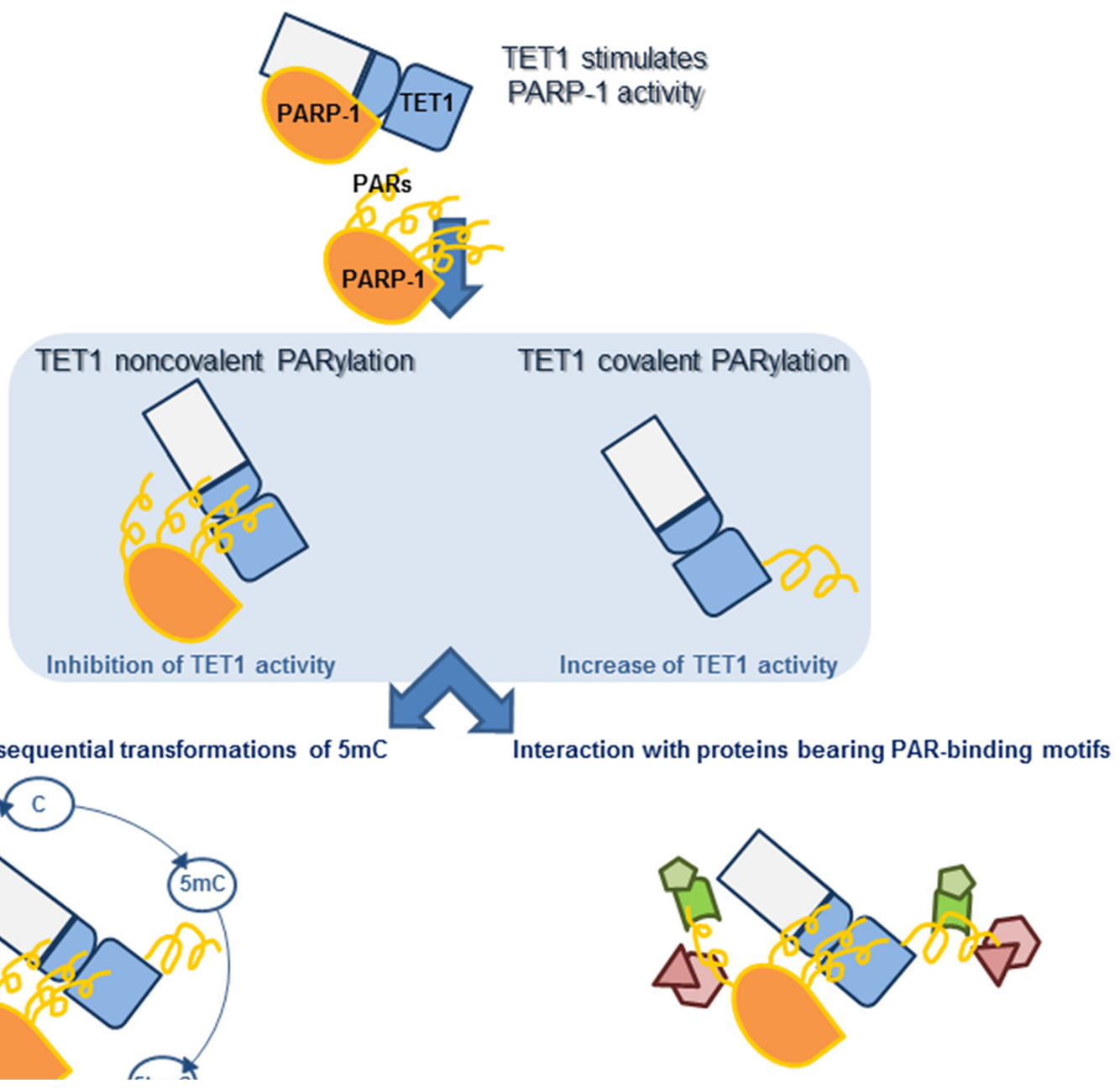

Figure 7: Model summarizing the possible outcomes of covalent and noncovalent PARylation of TET1 on its biological functions. TET 1 can stimulate the activity of PARP-1 independently of DNA damage. In turn, TET1 can be PARylated by PARP-1 both noncovalently and covalently with consequences on TET1 activity. PARylation of TET1 may regulate the hydroxylase activity during the different steps of the DNA demethylation processes. Apart from the regulation of TET activity, PARylation of TET1 may act in the assemblage of complexes containing PAR-interacting proteins involved in the regulation of DNA demethylation and transcription. 
inhibitors. The increase of $5 \mathrm{hmC}$ formation cannot be justified by the involvement of PARylation in the control of TET1 expression or recruitment onto genome. Rather, this finding suggests that PARs could suppress TET1 enzymatic activity as also indicated by the use of TALE constructs fused to the sole catalytic domain of TET1. Notably, TALE-TET1CD possesses PAR-binding motifs which interacting noncovalently with PARs may inhibit TET hydroxylase activity. The hypothesis of an inhibitory effect of PARs on TET enzymatic activity was validated measuring the total TET activity in cells after inhibition of PARylation. In addition, after the confirmation of a strong noncovalent interaction between PARs and TET1, the incubation of recombinant TET1 catalytic domain with PARs synthesised in vitro indicated that noncovalent PARylation of TET1 is effectively involved in the enzymatic repression. Further co-IP and pull-down experiments demonstrated an interaction between TET1 and PARP-1/ARTD1 which seems to be strengthened by PARs even though the proteins can also interact independently.

The identification of in vitro inhibitory action of noncovalent PARylation on TET1 enzyme is apparently in disagreement with the reduction of $5 \mathrm{hmC}$ levels observed after treatment of HEK293T cells with PARP inhibitors. Such in vivo effect of PAR depletion on genomic DNA is most likely to be the net result which also depends on the decrease of TET1 expression as well as on the failure of TET1 recruitment onto DNA mediated by PARs.

PARP-1/ARTD1 can modify target proteins covalently on glutamate, aspartate or lysine residues [61] and some proteins can undergo both covalent and noncovalent PARylation [10, 15, 22, 62]. In vitro experiments showed that TET1 can indeed be covalently modified by PARP-1/ARTD1 and this modification seems to have a different outcome on TET1 activity resulting in a stimulation of the enzyme. Notably, TET1 and PARP1/ARTD1 are also connected by the ability of TET1 to trigger PARylation in vitro in absence of activating nicked DNA. In this context, the covalent modification of TET1 has also been evidenced.

Collectively, these results enlarge the complexity of the cross-talk existing between TET1 and PARP-1/ ARTD1. In fact, apart from the involvement of PARylation in the transcriptional regulation of TET1 gene $[31,50]$ and recruitment of TET1 protein onto specific loci [51], our findings highlight for the first time a direct control of PARs over TET1 hydroxylase activity. In particular, a bimodal influence of noncovalent and covalent PARylation emerges on the regulation of TET1 enzymatic activity. These multiple connections between PARP-1/ARTD1 and TET1 are not surprising considering the different ways adopted by PARylation in the regulation of protein functions $[6,16]$ and above all the numerous roles played by TET1 in the regulation of epigenetic dynamics [54].

Accordingly, $5 \mathrm{hmC}$ can be an intermediate of both active and passive DNA demethylation [33, 34]. In particular, TET enzyme activity is not limited to the formation of $5 \mathrm{hmC}$ but it is also responsible for the transformation of $5 \mathrm{hmC}$ in its derivatives, $5 \mathrm{fC}$ and $5 \mathrm{caC}$, during the active DNA demethylation process [36, 37]. Besides the well-known involvement of PARP-1/ARTD1 in the BER pathway [3] which leads the reintroduction of unmethylated cytosines, a contribution of PARylation in the control of the sequential transformations of $5 \mathrm{mC}$ into $5 \mathrm{hmC}, 5 \mathrm{fC}$ or $5 \mathrm{caC}$ mediated by TETs can be suggested. Moreover, during active DNA demethylation the PARylation of TET1 itself could favour the assemblage of those DNA repair effectors known to be recruited on damaged DNA by PAR noncovalent interaction $[8,9,13]$.

It is noteworthy that TET1 is involved in transcriptional regulation even independently of its hydroxylase activity. This is also supported by the evidence that TET1, by its CXXC domain, preferentially binds to unmehylated CGIs where the hydroxylase activity is not required missing the $5 \mathrm{mC}$ substrate [63-65]. In this context, PARylated TET1 could limit the access of DNMT1 onto DNA preventing DNA methylation [19, 29, 64] and it can favour the binding of transcription factors that bind PARs noncovalently (Figure 7).

In conclusion, in this work we have identified for the first time a mechanism involved in the direct regulation of TET enzymatic activity mediated by PARylation. A deeper characterization of the interplay between TET1 and PARP1/ARTD1 also in relation with other post-translational modifications would highlight new mechanisms driving TET1 functions. This is relevant if considering that TET enzymes and $5 \mathrm{hmC}$ are not only involved in development and cell differentiation [34] but also in several pathological conditions including cancer [66-68] and neurodegenerative disorders [69-71].

\section{MATERIALS AND METHODS}

\section{Cell culture, treatment and transfection}

HEK293T cells were grown in high glucose DMEM (Sigma-Aldrich) containing 10\% FBS (SigmaAldrich), 2 mM L-glutamine (Sigma-Aldrich) and $50 \mathrm{U} /$ $\mathrm{ml}$ Penicillin-Streptomycin (Sigma-Aldrich). Treatments of cells were performed replacing medium every $24 \mathrm{hrs}$ with the PARP inhibitors PJ-34 (Sigma-Aldrich, final concentration $1 \mu \mathrm{M}$ ), and ABT-888 (Enzo Life Sciences, final concentration $1 \mu \mathrm{M}$ ). Transfection of HEK293T cells was performed by using Lipofectamine 2000 reagent (Life Technologies) adopting the manufacturer's protocol. TET1 silencing was obtained by using DsiRNA Duplex for TET1 gene (IDT Integrated DNA technologies, final concentration 10nM). TALE-TET1 overexpression plasmids namely JA740 (Addgene plasmid \# 49939), 
SL357 (Addgene plasmid \# 49936), MLM3713 (Addgene plasmid \# 49946), MLM3727 (Addgene plasmid \# 49961) were a gift from Keith Joung. In the manuscript, JA740, SL357, MLM3713, MLM3727 plasmids correspond to FL-1, FL-2, CD-1, CD-2.

\section{Antibodies}

The following monoclonal antibodies were used: PARP-1 (clone C2-10; Enzo Life Sciences), PAR (clone 10HA; Trevigen), TET1 (Genetex), Myc-tag (9E10 clone, hybridoma-conditioned medium), GST (Thermo), aTUB (Sigma-Aldrich), FLAG (Thermo Scientific Pierce Antibodies). The following polyclonal antibodies were used: PARP-1 (Enzo Life Sciences), PAR (10H, kind gift of A. Burkle), 5hmC (Active motif), Lamin B1 (Abcam).

\section{Western blot analysis}

Total cell lysates were prepared in RIPA buffer (50 mM Tris- $\mathrm{HCl}$ at $\mathrm{pH} 7.4,150 \mathrm{mM} \mathrm{NaCl}, 1 \% \mathrm{NP}-40$, $0.5 \%$ sodium deoxycholate, $0.1 \%$ SDS and $1 \mathrm{mM}$ EDTA) and normalized for protein concentration. Nuclei were obtained after incubation of cells for $15 \mathrm{~min}$ in ice with isolation buffer $(10 \mathrm{mM}$ Tris- $\mathrm{HCl}$ at $\mathrm{pH} 7.8,4 \mathrm{mM} \mathrm{MgCl}$ , $1 \mathrm{mM}$ EDTA, $0.5 \mathrm{mM}$ DTT, $1 \%$ Triton X-100, 0.25 $M$ Sucrose); pelleted nuclei were washed with isolation buffer without Triton X-100 and centrifuged. Each buffer was supplemented with protease inhibitor cocktail (Complete EDTA-free, Roche Applied Science). Protein extracts were resolved by SDS-PAGE in 6\% acrylamide/ bis-acrylamide gels, transferred onto Hybond-ECL nitrocellulose membranes (Amersham Biosciences) and probed with the indicated antibodies.

\section{Dot blot assay}

DNA was extracted with DNeasy Blood \& Tissue Kit (QIAGEN), denatured in $0.4 \mathrm{M} \mathrm{NaOH}, 10 \mathrm{mM}$ EDTA at $95^{\circ} \mathrm{C}$ for $10 \mathrm{~min}$ and then neutralized by adding an equal volume of cold $4 \mathrm{M}$ ammonium acetate ( $\mathrm{pH}$ 7.0). 2 -fold dilutions of denatured DNA samples were spotted on nitrocellulose membrane Hybond- $\mathrm{N}^{+}$(Amersham Biosciences) in an assembled Bio-Dot apparatus (Bio-Rad Laboratories). Vacuum was subsequently applied to filter. Blotted membrane was washed with 2X SSC buffer and air-dried. The membrane was then blocked with 5\% nonfat milk and incubated with anti $5 \mathrm{hmC}$ antibody (Active motif). Binding of an HRP-conjugated secondary antibody was visualized by chemiluminescence (Amersham ECL Western Blotting detection reagents). To control equal spotting of total DNA onto the membrane, the same blotted filter was then stained with $0.02 \%$ methylene blue in $0.3 \mathrm{M}$ sodium acetate $(\mathrm{pH} 5.2)$. A total of $3.5 \mu \mathrm{g}$ of
DNA was used for samples deriving from untransfected HEK293T cells, $1.75 \mu \mathrm{g}$ of DNA from TALE-TET1 FL samples and $350 \mathrm{ng}$ of DNA from TALE-TET1 CD samples. Densitometric analysis was performed by Quantity One Software (Bio-Rad Laboratories) according to manufacturer's instructions.

\section{ELISA-based quantification of $5 \mathrm{hmC}$}

Colorimetric quantification of $5 \mathrm{hmC}$ was performed by using the Quest 5-hmCTM DNA ELISA Kit (Zymo research) according to manufacturer's instructions.

\section{RNA extraction and quantitative RT-PCR}

Total RNA was isolated from cells by using RNeasy mini kit (Qiagen) following the manufacturer's instructions. RNase-free DNase (Qiagen) treatment was performed to eliminate contaminating DNA. Total RNA was subjected to reverse transcription using SuperScript VILO cDNA Synthesis Kit (Life Technologies). Transcriptional analysis was performed by quantitative RT-PCR (qRT-PCR) using iCycler IQ detection system (Bio-Rad). For quantitative PCR reactions, Taqman Gene Expression Assays (PARP-1 Hs00242302_m1; PARP-2 Hs00193931_m1; PARP-3 Hs00193946_m1; PARG Hs00608254_m1; GUSB Hs99999908_m1) and EXPRESS qPCR Supermix Universal (Life Technologies) were used. Measurement of gene expression was performed using the comparative cycle threshold method.

\section{Co-immunoprecipitation}

Nuclei isolated from HEK293T cells were lysed in Co-IP buffer (50 mM Tris-HCl pH 7.4, $250 \mathrm{mM} \mathrm{NaCl}$, $0.5 \% \mathrm{NP}-40$ and $2 \%$ glycerol) supplemented with protease inhibitors (Complete EDTA-free, Roche Applied Science). $\mathrm{NaCl}$ and glycerol concentrations were adjusted to 150 $\mathrm{mM}$ and $1 \%$, respectively. Lysates were then pre-cleared with Protein G-agarose beads or Protein A-agarose beads (Millipore) on a rotating shaker at $4{ }^{\circ} \mathrm{C}$ for $2.5 \mathrm{hrs}$. Precleared lysates were incubated with specific antibodies or relative normal control IgGs (Santa Cruz Biotechnology) on a rotating shaker overnight at $4^{\circ} \mathrm{C}$. Agarose beads, previously saturated with BSA $(1 \mu \mathrm{g} / \mu \mathrm{l})$ overnight, were added to the lysate/antibody solutions and incubated for 3 hrs on a rotating shaker at $4^{\circ} \mathrm{C}$. Subsequently, beads were washed 10 times in Co-IP wash buffer $(50 \mathrm{mM}$ Tris- $\mathrm{HCl}$ $\mathrm{pH} 7.4,150 \mathrm{mM} \mathrm{NaCl}, 0.5 \% \mathrm{NP}-40$ and $1 \%$ glycerol), proteins were eluted boiling in $2 \mathrm{X}$ Laemmli buffer and then analysed by Western blotting. 


\section{GST pull-down}

5 pmol of recombinant GST-TET1 or recombinant GST-tag (SignalChem) were incubated with $25 \mu 1$ of PBSwashed Glutathione Sepharose 4B (GE Healthcare) for 1 $\mathrm{hr}$ in rotation at $4^{\circ} \mathrm{C}$. After washing with equilibration buffer (50 mM Tris- $\mathrm{HCl} \mathrm{pH} 8.0,5 \mathrm{mM} \mathrm{MgCl} 2), 5 \mathrm{pmol}$ of unmodified recombinant PARP-1 (Enzo Life Sciences) or automodified recombinant PARP-1 were added to equilibration buffer and incubated with GST-TET1 or GST for $2 \mathrm{hrs}$ in rotation at $4^{\circ} \mathrm{C}$. Samples were washed 10 times with wash buffer ( $50 \mathrm{mM}$ Tris- $\mathrm{HCl} \mathrm{pH} 8.0,5 \mathrm{mM} \mathrm{MgCl}_{2}$, $150 \mathrm{mM} \mathrm{NaCl}, 0.1 \% \mathrm{NP}-40,1 \%$ glycerol) and elution was obtained boiling with one volume of $2 \mathrm{X}$ Laemmli sample buffer. PARP-1 automodification was obtained incubating 5 pmol of recombinant PARP-1 in PARP activity buffer (50 mM Tris-HCl pH 8.0, $5 \mathrm{mM} \mathrm{MgCl}, 0.2 \mathrm{mM}$ DTT, 3 $\left.\mu \mathrm{M} \mathrm{NAD}^{+}\right)$in presence of $200 \mathrm{ng}$ of DNAse I activated DNA (Enzo Life Sciences) for $45 \mathrm{~min}$ at $25^{\circ} \mathrm{C}$. GST pulldown was also performed in presence of $300 \mu \mathrm{g}$ of nuclear proteins with an incubation of $4 \mathrm{hrs}$ in rotation at $4^{\circ} \mathrm{C}$.

\section{Synthesis and purification of PARs}

Purification of PARs was performed as previously described [62]. Briefly, 1.5 units of human recombinant PARP-1 (Enzo Life Sciences) were incubated for $2 \mathrm{hrs}$ at $30^{\circ} \mathrm{C}$ in poly(ADP-ribosyl)ation buffer $(100 \mathrm{mM}$ Tris- $\mathrm{HCl}$ $\mathrm{pH} 8.0,10 \mathrm{mM} \mathrm{MgCl}, 20 \mathrm{mM}$ DTT, $200 \mu \mathrm{M} \mathrm{NAD}^{+}, 10 \%$ ethanol, 10\% glycerol) with $500 \mathrm{ng}$ of nicked DNA (Enzo Life Sciences). Reaction was stopped with $3 \mathrm{M}$ sodium acetate (pH 5.2) and 0.7 volume of isopropanol and kept overnight at $-20^{\circ} \mathrm{C}$. Samples were then centrifuged for $30 \mathrm{~min}$ at $16000 \mathrm{x}$ g and washed with $70 \%$ ethanol. The pellet was resuspended in $10 \mathrm{mM}$ Tris- $\mathrm{HCl}(\mathrm{pH} \mathrm{8.0)}, 1$ $\mathrm{mM}$ EDTA and $200 \mu \mathrm{g}$ of proteinase K (Sigma-Aldrich) and incubated overnight at $37^{\circ} \mathrm{C}$. Then, 1 volume of 1 $\mathrm{M} \mathrm{KOH} / 100 \mathrm{mM}$ EDTA was added and the samples were incubated for $2 \mathrm{hrs}$ at $37^{\circ} \mathrm{C}$, centrifuged and PARs were recovered by chloroform/isoamyl alcohol/ethanol precipitation. Pellets were resuspended in RNase DNasefree water (Millipore).

\section{PAR blot assay}

Recombinant proteins in equal molar amounts were dotted onto nitrocellulose membranes (Hybond ECL Amersham Pharmacia Biotech) in an assembled Bio-Dot apparatus (Bio-Rad). The blots were treated as described previously [62]. Briefly, blots were incubated in TBS-T (TBS- $0.05 \%$ Tween 20 ) containing PARs with or without dsDNA (double-stranded DNA) of salmon sperm as competitor, at a PAR:dsDNA ratio of 1:25 (w/w). After incubation for $3 \mathrm{hrs}$ at $21^{\circ} \mathrm{C}$, membranes were extensively washed with TBS-T and subjected to immunoblotting using mouse monoclonal anti PAR antibody (10 HA, Trevigen) and goat anti-mouse horseradish peroxidase conjugated antibody (Santa Cruz Biotechnology). Recombinant H2B (histone 2B, Sigma-Aldrich) was used as positive control while GST as the negative one.

\section{In vitro TET enzymatic activity analysis}

TET enzymatic activity was measured by using the ELISA-based Epigenase 5mC Hydroxylase TET Activity/Inhibition Assay Kit (Epigentek) according to manufacturer's instructions. Incubation time of TET1 recombinant enzyme/nuclear lysates was extended to two hrs.

\section{In vitro PARylation assay}

7 pmol of GST-TET1 (SignalChem) or recombinant GST-tag were incubated with $25 \mu 1$ of PBS-washed Glutathione Sepharose 4B (GE Healthcare) for $1 \mathrm{hr}$ in rotation at $4{ }^{\circ} \mathrm{C}$. After washing with equilibration buffer (50 mM Tris- $\mathrm{HCl} \mathrm{pH} 8.0,5 \mathrm{mM} \mathrm{MgCl}$ ), 3.5 pmol of recombinant PARP-1 (Enzo Life Sciences) were added to PARP activity buffer (50 mM Tris- $\mathrm{HCl} \mathrm{pH} \mathrm{8.0,5} \mathrm{mM}$ $\mathrm{MgCl}_{2}, 0.2 \mathrm{mM}$ DTT, $3 \mu \mathrm{M} \mathrm{NAD}^{+}$) in presence of DNAse I activated DNA (Enzo Life Sciences) and incubated with GST-TET1 or GST at $25^{\circ} \mathrm{C}$ for different time. Reaction was stopped adding one volume of $2 \mathrm{X}$ Laemmli sample buffer. For in vitro TET activity of covalently PARylated GST-TET1, elution was performed in $50 \mathrm{mM}$ Tris- $\mathrm{HCl}$ pH 8.0 and $20 \mathrm{mM}$ reduced glutathione after extensive incubations with detergent containing buffer $(50 \mathrm{mM}$ Tris$\mathrm{HCl} \mathrm{pH} 8.0,5 \mathrm{mM} \mathrm{MgCl}, 200 \mathrm{mM} \mathrm{NaCl}, 0.1 \% \mathrm{NP}-40$, $1 \%$ glycerol) to wash out PARP-1 protein. Experiments were also performed without DNAse I activated DNA incubating $1 \mathrm{pmol}$ of GST-TET1 or GST in presence of 0.4 pmol of PARP-1 for different time or incubating 9, 1.8, 2.7, $3.6 \mathrm{pmol}$ of GST-TET1 or GST in presence of $9 \mathrm{pmol}$ of PARP-1 for $15 \mathrm{~min}$ at $25^{\circ} \mathrm{C}$.

\section{Statistics}

Values are expressed as mean \pm SEM. Paired Student $t$-test or ANOVA with post hoc Tukey's test were used to compare results between different groups. Significance was accepted at the level of $P<0.05$.

\section{ACKNOWLEDGMENTS}

We would like to thank Dr. J. Keith Joung (Massachusetts General Hospital, Charlestown, USA) for providing TALE-TET1 plasmids and Dr. Marco Lalle (Istituto Superiore di Sanità, Rome, Italy) for useful 
advices.

\section{FUNDING}

This research was supported by: Italian Ministry of University and Research (MIUR) (P.C.: FIRBRBIN06E9Z8_003), Avvio alla Ricerca 2013 and 2014 projects by "Sapienza" University of Rome (F.C. prot. C26N13AAA5; prot. C26N14FTSJ), Progetti di Ateneo by "Sapienza" University of Rome (M.Z. prot. C26A14932L; prot. C26A134WJ2; prot. C26A12PN9T).

\section{CONFLICT OF INTERESTS STATEMENT}

The authors declare no conflict of interests.

\section{REFERENCES}

1. Hottiger MO, Hassa PO, Luscher B, Schuler H and KochNolte F. Toward a unified nomenclature for mammalian ADP-ribosyltransferases. Trends in biochemical sciences 2010; 35(4):208-219.

2. Hassa PO and Hottiger MO. The diverse biological roles of mammalian PARPS, a small but powerful family of polyADP-ribose polymerases. Front Biosci. 2008; 13:30463082 .

3. Schreiber V, Dantzer F, Ame JC and de Murcia G. Poly(ADP-ribose): novel functions for an old molecule. Nature reviews. 2006; 7:517-528.

4. Zaja R, Mikoc A, Barkauskaite E and Ahel I. Molecular Insights into Poly(ADP-ribose) Recognition and Processing. Biomolecules 2012; 3:1-17.

5. Beck C, Robert I, Reina-San-Martin B, Schreiber V and Dantzer F. Poly(ADP-ribose) polymerases in doublestrand break repair: focus on PARP1,PARP2 and PARP3. Experimental cell research 2014; 329:18-25.

6. Burkle A and Virag L. Poly(ADP-ribose): PARadigms and PARadoxes. Molecular aspects of medicine 2013; 34:10461065.

7. Bacalini MG, Di Lonardo D, Catizone A, Ciccarone F, Bruno T, Zampieri M, Guastafierro T, Calabrese R, Fanciulli M, Passananti C, Caiafa P, Reale A. Poly(ADPribosyl)ation affects stabilization of Che-1 protein in response to DNA damage. DNA Repair (Amst) 2011; 10:380-9.

8. El-Khamisy SF, Masutani M, Suzuki H and Caldecott KW. A requirement for PARP-1 for the assembly or stability of XRCC1 nuclear foci at sites of oxidative DNA damage. Nucleic acids research. 2003; 31:5526-5533.

9. Fischer JM, Popp O, Gebhard D, Veith S, Fischbach A, Beneke S, Leitenstorfer A, Bergemann J, Scheffner M, Ferrando-May E, Mangerich A and Burkle A. Poly(ADPribose)-mediated interplay of XPA and PARP1 leads to reciprocal regulation of protein function. The FEBS journal 2014 281:3625-3641.

10. Malanga M, Pleschke JM, Kleczkowska HE and Althaus FR. Poly(ADP-ribose) binds to specific domains of p53 and alters its DNA binding functions. The Journal of biological chemistry. 1998; 273:11839-11843.

11. Guastafierro T, Cecchinelli B, Zampieri M, Reale A, Riggio G, Sthandier O, Zupi G, Calabrese L and Caiafa P. CCCTC-binding factor activates PARP-1 affecting DNA methylation machinery. The Journal of biological chemistry. 2008; 283:21873-21880.

12. Sajish $M$ and Schimmel P. A human tRNA synthetase is a potent PARP1-activating effector target for resveratrol. Nature 2015; 519:370-3.

13. Krietsch J, Rouleau M, Pic E, Ethier C, Dawson TM, Dawson VL, Masson JY, Poirier GG and Gagne JP. Reprogramming cellular events by poly(ADP-ribose) binding proteins. Molecular aspects of medicine 2013; 34:10661087.

14. Guastafierro T, Catizone A, Calabrese R, Zampieri M, Martella O, Bacalini MG, Reale A, Di Girolamo M, Miccheli M, Farrar D, Klenova E, Ciccarone F and Caiafa P. ADP-ribose polymer depletion leads to nuclear Ctcf relocalization and chromatin rearrangement. The Biochemical journal 2013; 449:623-630.

15. Kanai M, Hanashiro K, Kim SH, Hanai S, Boulares AH, Miwa M and Fukasawa K. Inhibition of Crm1-p53 interaction and nuclear export of p53 by poly(ADP-ribosyl) ation. Nature cell biology. 2007; 9:1175-1183.

16. Krishnakumar R and Kraus WL. The PARP side of the nucleus: molecular actions, physiological outcomes, and clinical targets. Molecular cell 2010; 39:8-24.

17. Krishnakumar $\mathrm{R}$ and Kraus WL. PARP-1 regulates chromatin structure and transcription through a KDM5Bdependent pathway. Molecular cell 2010; 39:736749.

18. Pavri R, Lewis B, Kim TK, Dilworth FJ, ErdjumentBromage H, Tempst P, de Murcia G, Evans R, Chambon $\mathrm{P}$ and Reinberg D. PARP-1 determines specificity in a retinoid signaling pathway via direct modulation of mediator. Molecular cell. 2005; 18:83-96.

19. Reale A, Matteis GD, Galleazzi G, Zampieri M and Caiafa P. Modulation of DNMT1 activity by ADP-ribose polymers. Oncogene. 2005; 24:13-19.

20. Martinez-Zamudio R and Ha HC. Histone ADP-ribosylation facilitates gene transcription by directly remodeling nucleosomes. Molecular and cellular biology 2012; 32:24902502.

21. Messner S, Altmeyer M, Zhao H, Pozivil A, Roschitzki B, Gehrig P, Rutishauser D, Huang D, Caflisch A and Hottiger MO. PARP1 ADP-ribosylates lysine residues of the core histone tails. Nucleic acids research 2010; 38:6350-6362.

22. Farrar D, Rai S, Chernukhin I, Jagodic M, Ito Y, Yammine S, Ohlsson R, Murrell A and Klenova E. Mutational analysis of the poly(ADP-ribosyl)ation sites of the transcription 
factor CTCF provides an insight into the mechanism of its regulation by poly(ADP-ribosyl)ation. Molecular and cellular biology 2010; 30:1199-1216.

23. Gao F, Kwon SW, Zhao Y and Jin Y. PARP1 poly(ADPribosyl)ates Sox2 to control Sox2 protein levels and FGF4 expression during embryonic stem cell differentiation. The Journal of biological chemistry. 2009; 284:22263-22273.

24. Quenet D, Gasser V, Fouillen L, Cammas F, SanglierCianferani S, Losson R and Dantzer F. The histone subcode: poly(ADP-ribose) polymerase-1 (Parp-1) and Parp-2 control cell differentiation by regulating the transcriptional intermediary factor TIF1beta and the heterochromatin protein HP1alpha. Faseb J. 2008; 22:3853-3865.

25. Sala A, La Rocca G, Burgio G, Kotova E, Di Gesu D, Collesano M, Ingrassia AM, Tulin AV and Corona DF. The nucleosome-remodeling ATPase ISWI is regulated by polyADP-ribosylation. PLoS biology. 2008; 6:e252.

26. Lodhi N, Kossenkov AV and Tulin AV. Bookmarking promoters in mitotic chromatin: poly(ADP-ribose) polymerase-1 as an epigenetic mark. Nucleic acids research 2014; 42:7028-7038.

27. Le May N, Iltis I, Ame JC, Zhovmer A, Biard D, Egly JM, Schreiber V and Coin F. Poly (ADP-ribose) glycohydrolase regulates retinoic acid receptor-mediated gene expression. Molecular cell 2012; 48:785-798.

28. De Vos M, El Ramy R, Quenet D, Wolf P, Spada F, Magroun N, Babbio F, Schreiber V, Leonhardt H, Bonapace IM and Dantzer F. Poly(ADP-ribose) polymerase 1 (PARP1) associates with E3 ubiquitin-protein ligase UHRF1 and modulates UHRF1 biological functions. The Journal of biological chemistry 2014; 289:16223-16238.

29. Zampieri M, Passananti C, Calabrese R, Perilli M, Corbi N, De Cave F, Guastafierro T, Bacalini MG, Reale A, Amicosante G, Calabrese L, Zlatanova J and Caiafa P. Parp1 localizes within the Dnmt1 promoter and protects its unmethylated state by its enzymatic activity. PloS one 2009; 4:e4717.

30. Ciccarone F, Klinger FG, Catizone A, Calabrese R, Zampieri M, Bacalini MG, De Felici M and Caiafa P. Poly(ADP-ribosyl)ation acts in the DNA demethylation of mouse primordial germ cells also with DNA damageindependent roles. PloS one 2012; 7:e46927.

31. Ciccarone F, Valentini E, Bacalini MG, Zampieri M, Calabrese R, Guastafierro T, Mariano G, Reale A, Franceschi $\mathrm{C}$ and Caiafa P. Poly(ADP-ribosyl)ation is involved in the epigenetic control of TET1 gene transcription. Oncotarget 2014; 5:10356-10367.

32. Shen L and Zhang Y. 5-Hydroxymethylcytosine: generation, fate, and genomic distribution. Current opinion in cell biology 2013; 25:289-296.

33. Piccolo FM and Fisher AG. Getting rid of DNA methylation. Trends in cell biology 2014; 24:136-143.

34. Sun W, Guan M and Li X. 5-hydroxymethylcytosinemediated DNA demethylation in stem cells and development. Stem cells and development 2014; 23:923930.

35. Hashimoto H, Liu Y, Upadhyay AK, Chang Y, Howerton SB, Vertino PM, Zhang X and Cheng X. Recognition and potential mechanisms for replication and erasure of cytosine hydroxymethylation. Nucleic acids research 2012; 40:48414849.

36. Ito S, Shen L, Dai Q, Wu SC, Collins LB, Swenberg JA, He $\mathrm{C}$ and Zhang Y. Tet proteins can convert 5-methylcytosine to 5-formylcytosine and 5-carboxylcytosine. Science 2011; 333:1300-1303.

37. Shen L, Wu H, Diep D, Yamaguchi S, D'Alessio AC, Fung HL, Zhang $\mathrm{K}$ and Zhang Y. Genome-wide analysis reveals TET- and TDG-dependent 5-methylcytosine oxidation dynamics. Cell 2013; 153:692-706.

38. Bachman M, Uribe-Lewis S, Yang X, Williams M, Murrell A and Balasubramanian S. 5-Hydroxymethylcytosine is a predominantly stable DNA modification. Nature chemistry 2014; 6:1049-1055.

39. Globisch D, Munzel M, Muller M, Michalakis S, Wagner M, Koch S, Bruckl T, Biel M and Carell T. Tissue distribution of 5-hydroxymethylcytosine and search for active demethylation intermediates. PloS one 2010; 5:e15367.

40. Kinney SM, Chin HG, Vaisvila R, Bitinaite J, Zheng Y, Esteve PO, Feng S, Stroud H, Jacobsen SE and Pradhan $\mathrm{S}$. Tissue-specific distribution and dynamic changes of 5-hydroxymethylcytosine in mammalian genomes. The Journal of biological chemistry 2011; 286:24685-24693.

41. Hon GC, Song CX, Du T, Jin F, Selvaraj S, Lee AY, Yen CA, Ye Z, Mao SQ, Wang BA, Kuan S, Edsall LE, Zhao $\mathrm{BS}, \mathrm{Xu} \mathrm{GL}, \mathrm{He} \mathrm{C}$ and Ren B. $5 \mathrm{mC}$ oxidation by Tet2 modulates enhancer activity and timing of transcriptome reprogramming during differentiation. Molecular cell 2014; 56:286-297.

42. Szulwach KE, Li X, Li Y, Song CX, Han JW, Kim S, Namburi S, Hermetz K, Kim JJ, Rudd MK, Yoon YS, Ren $\mathrm{B}, \mathrm{He} \mathrm{C}$ and Jin P. Integrating 5-hydroxymethylcytosine into the epigenomic landscape of human embryonic stem cells. PLoS genetics 2011; 7:e1002154.

43. Williams K, Christensen J, Pedersen MT, Johansen JV, Cloos PA, Rappsilber J and Helin K. TET1 and hydroxymethylcytosine in transcription and DNA methylation fidelity. Nature 2011; 473:343-348.

44. Yu M, Hon GC, Szulwach KE, Song CX, Zhang L, Kim A, Li X, Dai Q, Shen Y, Park B, Min JH, Jin P, Ren B and He C. Base-resolution analysis of 5-hydroxymethylcytosine in the mammalian genome. Cell 2012; 149:1368-1380.

45. Iurlaro M, Ficz G, Oxley D, Raiber EA, Bachman M, Booth MJ, Andrews S, Balasubramanian S and Reik W. A screen for hydroxymethylcytosine and formylcytosine binding proteins suggests functions in transcription and chromatin regulation. Genome biology 2013; 14:R119.

46. Spruijt CG, Gnerlich F, Smits AH, Pfaffeneder T, Jansen 
PW, Bauer C, Munzel M, Wagner M, Muller M, Khan F, Eberl HC, Mensinga A, Brinkman AB, Lephikov K, Muller U, Walter J, et al. Dynamic readers for 5-(hydroxy) methylcytosine and its oxidized derivatives. Cell 2013; 152:1146-1159

47. Kellinger MW, Song CX, Chong J, Lu XY, He C and Wang D. 5-formylcytosine and 5-carboxylcytosine reduce the rate and substrate specificity of RNA polymerase II transcription. Nature structural \& molecular biology 2012; 19:831-833.

48. Neri F, Incarnato D, Krepelova A, Rapelli S, Anselmi F, Parlato C, Medana C, Dal Bello F and Oliviero S. Single Base Resolution Analysis of 5-Formyl and 5-Carboxyl Cytosine Reveals Promoter DNA Methylation Dynamics. Cell reports 2015.

49. Raiber EA, Beraldi D, Ficz G, Burgess HE, Branco MR, Murat P, Oxley D, Booth MJ, Reik W and Balasubramanian S. Genome-wide distribution of 5-formylcytosine in embryonic stem cells is associated with transcription and depends on thymine DNA glycosylase. Genome biology 2012; 13:R69.

50. Roper SJ, Chrysanthou S, Senner CE, Sienerth A, Gnan S, Murray A, Masutani M, Latos P and Hemberger M. ADPribosyltransferases Parp1 and Parp7 safeguard pluripotency of ES cells. Nucleic acids research 2014; 42:8914-8927.

51. Fujiki K, Shinoda A, Kano F, Sato R, Shirahige K and Murata M. PPARgamma-induced PARylation promotes local DNA demethylation by production of 5-hydroxymethylcytosine. Nature communications 2013; 4:2262.

52. Joung JK and Sander JD. TALENs: a widely applicable technology for targeted genome editing. Nature reviews 2013; 14:49-55.

53. Maeder ML, Angstman JF, Richardson ME, Linder SJ, Cascio VM, Tsai SQ, Ho QH, Sander JD, Reyon D, Bernstein BE, Costello JF, Wilkinson MF and Joung JK.Targeted DNA demethylation and activation of endogenous genes using programmable TALE-TET1 fusion proteins. Nature biotechnology 2013; 31:1137-1142.

54. Delatte B, Deplus R and Fuks F. Playing TETris with DNA modifications. The EMBO journal 2014; 33:1198-1211.

55. Dehennaut V, Leprince $\mathrm{D}$ and Lefebvre $\mathrm{T}$. O-GlcNAcylation, an Epigenetic Mark. Focus on the Histone Code, TET Family Proteins, and Polycomb Group Proteins. Frontiers in endocrinology 2014; 5:155.

56. Shi FT, Kim H, Lu W, He Q, Liu D, Goodell MA, Wan $\mathrm{M}$ and Songyang Z. Ten-eleven translocation 1 (Tet1) is regulated by $\mathrm{O}$-linked $\mathrm{N}$-acetylglucosamine transferase (Ogt) for target gene repression in mouse embryonic stem cells. The Journal of biological chemistry 2013; 288:2077620784.

57. Zhang Q, Liu X, Gao W, Li P, Hou J, Li J and Wong J. Differential regulation of the ten-eleven translocation (TET) family of dioxygenases by O-linked beta-N- acetylglucosamine transferase (OGT). The Journal of biological chemistry 2014; 289:5986-5996.

58. Bauer C, Gobel K, Nagaraj N, Colantuoni C, Wang M, Muller U, Kremmer E, Rottach A and LeonhardtOGlcNAcylation by the O-Linked N-Acetylglucosamine Transferase (OGT). The Journal of biological chemistry 2015; 290:4801-4812.

59. Deplus R, Delatte B, Schwinn MK, Defrance M, Mendez J, Murphy N, Dawson MA, Volkmar M, Putmans P, Calonne E, Shih AH, Levine RL, Bernard O, Mercher T, Solary E, Urh M, et al. TET2 and TET3 regulate GlcNAcylation and H3K4 methylation through OGT and SET1/COMPASS.The EMBO journal 2013; 32:645-655.

60. Dhliwayo N, Sarras MP, Jr., Luczkowski E, Mason SM and Intine RV. Parp inhibition prevents ten-eleven translocase enzyme activation and hyperglycemia-induced DNA demethylation. Diabetes 2014; 63:3069-3076.

61. Rosenthal F, Messner S, Roschitzki B, Gehrig P, Nanni P and Hottiger MO. Identification of distinct amino acids as ADP-ribose acceptor sites by mass spectrometry. Methods in molecular biology 2011; 780:57-66.

62. Zampieri M, Guastafierro $\mathrm{T}$, Calabrese R, Ciccarone F, Bacalini MG, Reale A, Perilli M, Passananti C and Caiafa P. ADP-ribose polymers localized on Ctcf-Parp1Dnmt complex prevent methylation of Ctcf target sites. TheBiochemical journal 2012; 441:645-652.

63. Jin C, Lu Y, Jelinek J, Liang S, Estecio MR, Barton MC and Issa JP. TET1 is a maintenance DNA demethylase that prevents methylation spreading in differentiated cells. Nucleic acids research 2014; 42:6956-6971.

64. Williams K, Christensen J and Helin K. DNA methylation: TET proteins-guardians of $\mathrm{CpG}$ islands? EMBO reports 2011; 13:28-35.

65. Wu H, D'Alessio AC, Ito S, Xia K, Wang Z, Cui K, Zhao K, Sun YE and Zhang Y. Dual functions of Tet1 in transcriptional regulation in mouse embryonic stem cells. Nature 2011; 473:389-393.

66. Ko M, Huang Y, Jankowska AM, Pape UJ, Tahiliani M, Bandukwala HS, An J, Lamperti ED, Koh KP, Ganetzky R, Liu XS, Aravind L, Agarwal S, Maciejewski JP and Rao A. Impaired hydroxylation of 5-methylcytosine in myeloid cancers with mutant TET2. Nature 2010; 468:839-843.

67. Kroeze LI, van der Reijden BA and Jansen JH. 5-Hydroxymethylcytosine: An epigenetic mark frequently deregulated in cancer. Biochimica et biophysica acta 2015; 1855:144-154.

68. Yang H, Liu Y, Bai F, Zhang JY, Ma SH, Liu J, Xu ZD, Zhu HG, Ling ZQ, Ye D, Guan KL and Xiong Y. Tumor development is associated with decrease of TET gene expression and 5-methylcytosine hydroxylation. Oncogene 2013; 32:663-669.

69. Al-Mahdawi S, Virmouni SA and Pook MA. The emerging role of 5-hydroxymethylcytosine in neurodegenerative diseases. Frontiers in neuroscience 2014; 8:397. 
70. Calabrese R, Valentini E, Ciccarone F, Guastafierro T, Bacalini MG, Ricigliano VA, Zampieri M, Annibali V, Mechelli R, Franceschi C, Salvetti M and Caiafa P. TET2 gene expression and 5-hydroxymethylcytosine level in multiple sclerosis peripheral blood cells. Biochimica et biophysica acta 2014; 1842:1130-1136.

71. Coppieters N, Dieriks BV, Lill C, Faull RL, Curtis MA and Dragunow M. Global changes in DNA methylation and hydroxymethylation in Alzheimer's disease human brain. Neurobiology of aging 2014; 35:1334-1344. 